\title{
STOP 9: Upper Daugava spillway valley and associated gully network at Vasargelišķi
}

\author{
Juris Soms ${ }^{\mathrm{a}}$ and Vitālijs Zelčs ${ }^{\mathrm{b}}$ \\ ${ }^{a}$ Daugavpils University, Latvia \\ ${ }^{\mathrm{b}}$ University of Latvia, Latvia
}

The stop site at the Vasargelišķi village $\left(55^{\circ} 54^{\prime} 56^{\prime \prime} \mathrm{N}, 26^{\circ} 49^{\prime} 05^{\prime \prime} \mathrm{E}\right)$ is located about 6 $\mathrm{km}$ east of Daugavpils, within the Upper Daugava spillway valley.

The Upper Daugava spillway valley is one of the oldest and largest in Latvia. It stretches for a distance of $50 \mathrm{~km}$ between Krāslava town and Krauja village (Fig. 9.1). The spillway valley was carved in the lowermost part of the Upper Daugava depression through the icemarginal belts of the Dagda and Kaldabruna phases. It was formed as a result of the interplay between meltwater discharge from the Polatsk and Nīcgale proglacial lakes. The Upper Daugava spillway separates the Latgale Upland from the Augšzeme Upland.

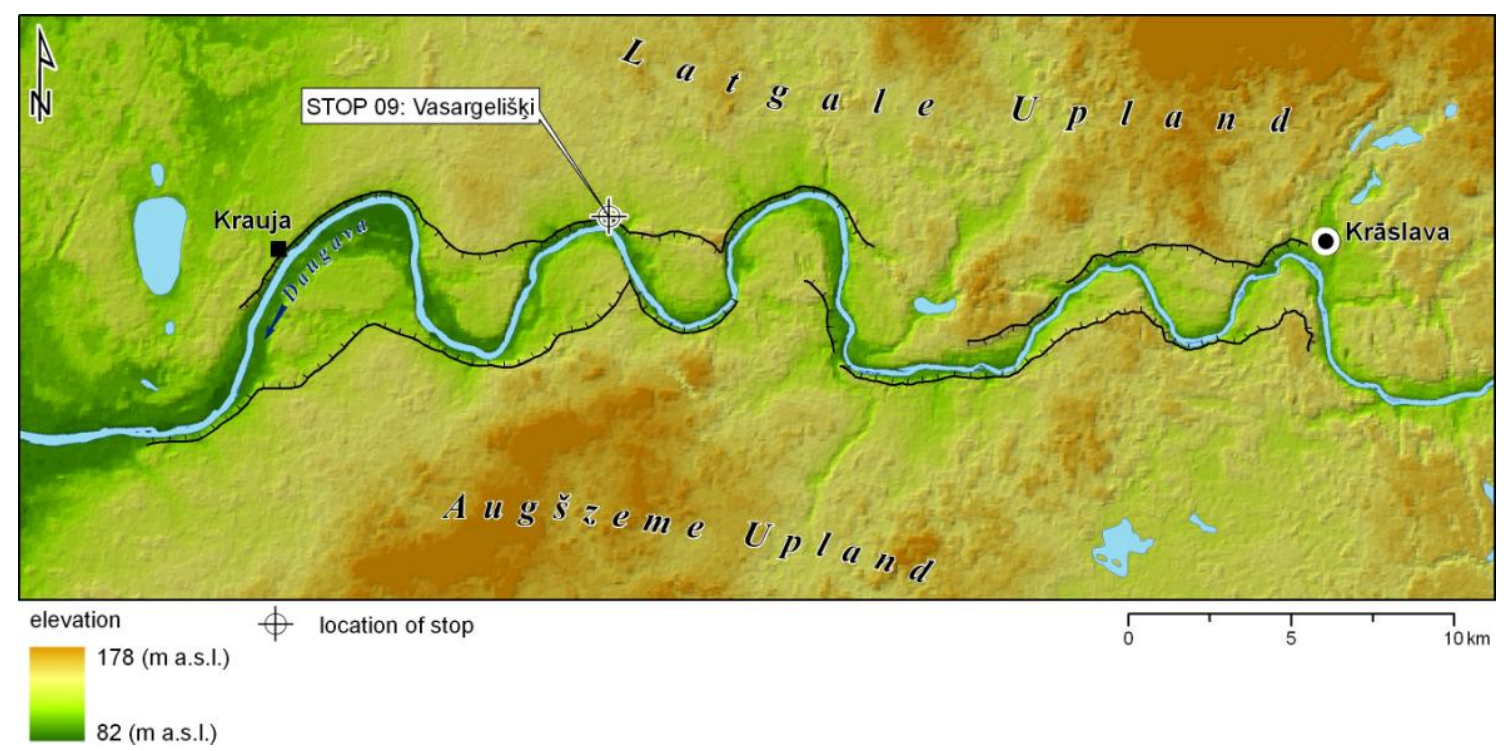

Fig. 9.1. Digital elevation model of the Upper Daugava spillway valley and surroundings.

Nowadays the spillway valley is maintained by the River Daugava in its course from the Polatsk Lowland in the east to the East-Latvian Lowland in the west. In this stretch the River Daugava valley is terraced. The cross-profile of the valley is asymmetric, with mainly erosional terraces (Eberhards 1972). Only the first (I) or youngest terrace in this stretch of the Daugava River valley is aggradational (ibid.). Two floodplain levels occur in the valley floor. Entrenched meandering of the river flow is characterized by a relatively high stream gradient of $0.16 \mathrm{~m} \mathrm{~km}^{-1}$. The valley in this stretch is up to $45 \mathrm{~m}$ deep and its width varies from 0.5 to $1.2 \mathrm{~km}$; gentle slopes along the convex banks of terraces alternate with very steep slopes along the undercut concave banks of the meander bands. Analysis of historical maps indicates that the configuration of the river channel is rather stable; the calculated mean rate of lateral erosion is $0.45 \mathrm{~m} \mathrm{y}^{-1}$.

The local relief and geology of the area were largely formed by glacial processes during Pleistocene glaciations, particularly by the last Weichselian event (Zelčs and Markots 2004; Zelčs et al. 2011). However, the valley of the River Daugava as a geomorphological feature differs from the rest of the landforms in this region because it is a proglacial spillway initially formed by ice sheet meltwater streams during the Late Pleistocene and subsequently modified by fluvial processes in the Holocene (Eberhards 1972; Āboltiņš 1994). 
The geological structure of the territory is rather complex both in horizontal and vertical sections. The bedrock surface is represented mainly by poorly-cemented sandstone of Upper Devonian origin and is uneven due to the presence of some fragments of buried preQuaternary valleys (Eberhards 1972). The hypsometric position of the sub-Quaternary surface ranges from $80 \mathrm{~m}$ to $90 \mathrm{~m}$ (Juškevičs and Skrebels 2003). Thereby, considering the presentday local altitudes, along the flanks of the spillway valley the bedrock is capped by relatively thick, up 40-50 m on average, Quaternary cover, whereas at the bottom of the spillway valley the Upper Devonian bedrock is exposed or covered by thin drift in many places.

The vertical cross-section of the Quaternary strata consists of glacial and glacioaquatic deposits formed by several Pleistocene glaciations. The spatial geological structure of the study area surface is characterized by an alternation of boulder sandy and clayey diamicton, basal till deposits or glaciolacustrine clay and silt deposits of the last glaciation; these are sporadically covered by younger Holocene deposits (Juškevičs and Skrebels 2003). It follows that the low hypsometric position of the bedrock and the thickness of the covering Quaternary strata determine that the deposits lying at the surface and exposed to exogenic geological processes mainly consist of erodible Late Pleistocene glacial, glaciofluvial and glaciolacustrine sediments.

Despite the fact that studies focused on the morphology and development of the spillway valley have been conducted since the 1930s (Sleinis 1936), these matters are still under discussion. According to data given in scientific publications, the number of terraces identified by different authors in the spillway valley varies greatly. Thus, Majore (1962) observed five terraces, whereas Eberhards (1972) distinguished eight terraces. The terraces have developed during several phases of incision related to the evolution of the Polatsk and Nicgale ice dammed glacial lakes and associated formation of glacial meltwater outbursts during the Younger Dryas-Allerød (Eberhards 1972). Field surveys performed during the last years with the application of high-precision GPS and GIS techniques indicate that only the 1st and 2nd terraces are easily recognizable, whereas the upper terraces do not have explicit edges and are encountered only in some short stretches of the valley. In addition, the process of identification of terraces is more complicated due to the glaciokarst kettles on their surfaces. These kettles are present as semi-circular, slightly elongated funnel-like closed depressions, which form groups, constituting an undulating belt in planar view (Fig. 9.2).

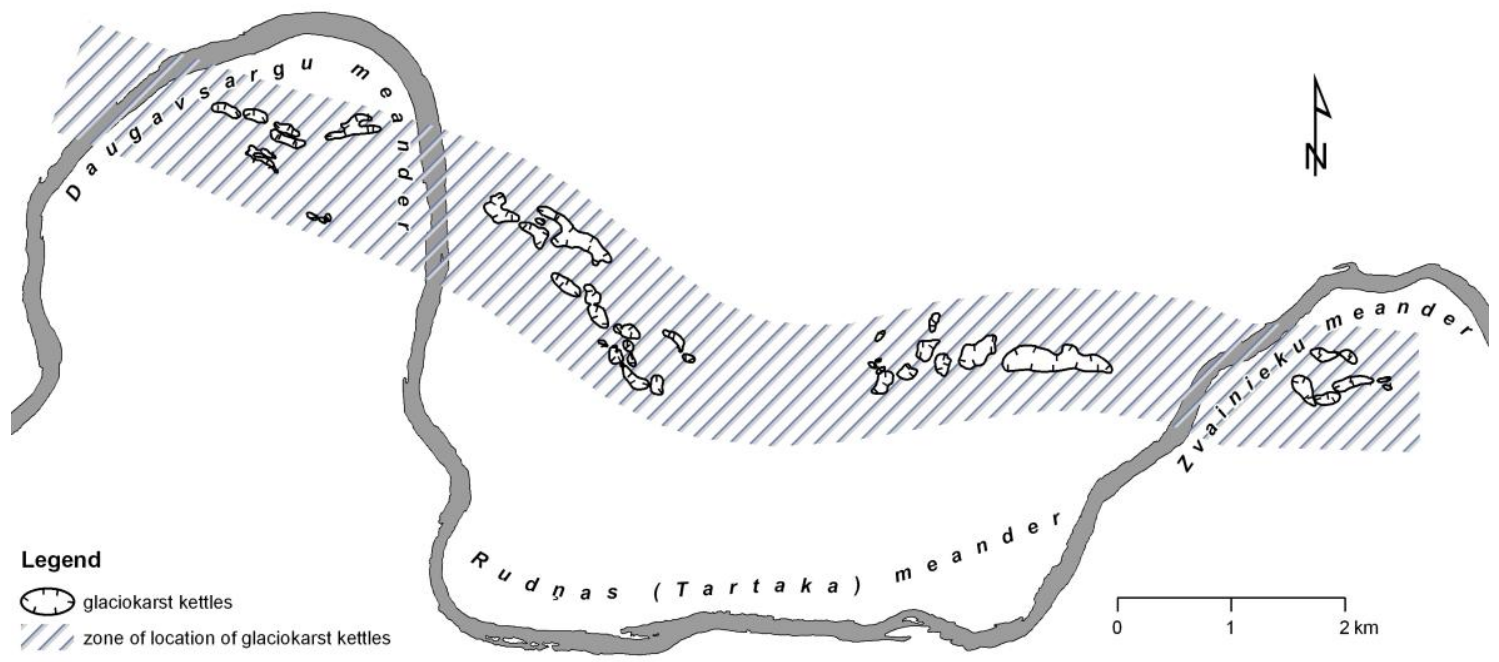

Fig. 9.2. Geographical distribution of glaciokarst kettles within the middle part of the Upper Daugava spillway valley.

In some of these kettles small raised bogs have formed. This made it possible to obtain a core from the bottom part of a peat layer in one of the glaciokarst kettles, in the interval 8.5$6.35 \mathrm{~m}$, for $\mathrm{AMS}{ }^{14} \mathrm{C}$ dating. In order to construct a timescale, three samples from depths of 
$8.20 \mathrm{~m}, 7.35 \mathrm{~m}$ and 6.35 below the surface were dated by $\mathrm{AMS}{ }^{14} \mathrm{C}$ at the Poznan Radiocarbon Laboratory. These dates were calibrated at the one- $\delta$ confidence level using the online version of the OxCal v.4.2 software. (Bronk Ramsey and Lee 2013) and the IntCall3 calibration curve (Reimer et al. 2013). The plant macrofossil fragments collected from the peat samples yielded AMS radiocarbon ages of 10,704 $\pm 50 \mathrm{cal} \mathrm{yr} \mathrm{BP,} 8510 \pm 40 \mathrm{cal} \mathrm{yr}$ BP and $7935 \pm 35$ cal yr BP, respectively (unpublished data).

Fluvial forms created by gully erosion are also characteristic features of the spillway valley (Fig. 9.3). There are more than 350 permanent gullies differing in size and morphology dissecting the main valley sides along the 50-km-long stretch from Krāslava down to Krauja. Total gully length per unit area in some places reaches $4.2 \mathrm{~km} \mathrm{~km}^{-2}$ (Soms 2006). Local altitudes range between c. $90 \mathrm{~m}$ a.s.1 at the valley bottom and $150-170 \mathrm{~m}$ a.s.l in the adjoining hummocky and undulating areas typical of the uplands of Latvia. This also determines the considerable average difference in local relief, which is about $25-45 \mathrm{~m}$, as well as the high position of headwater catchments above the local base level.

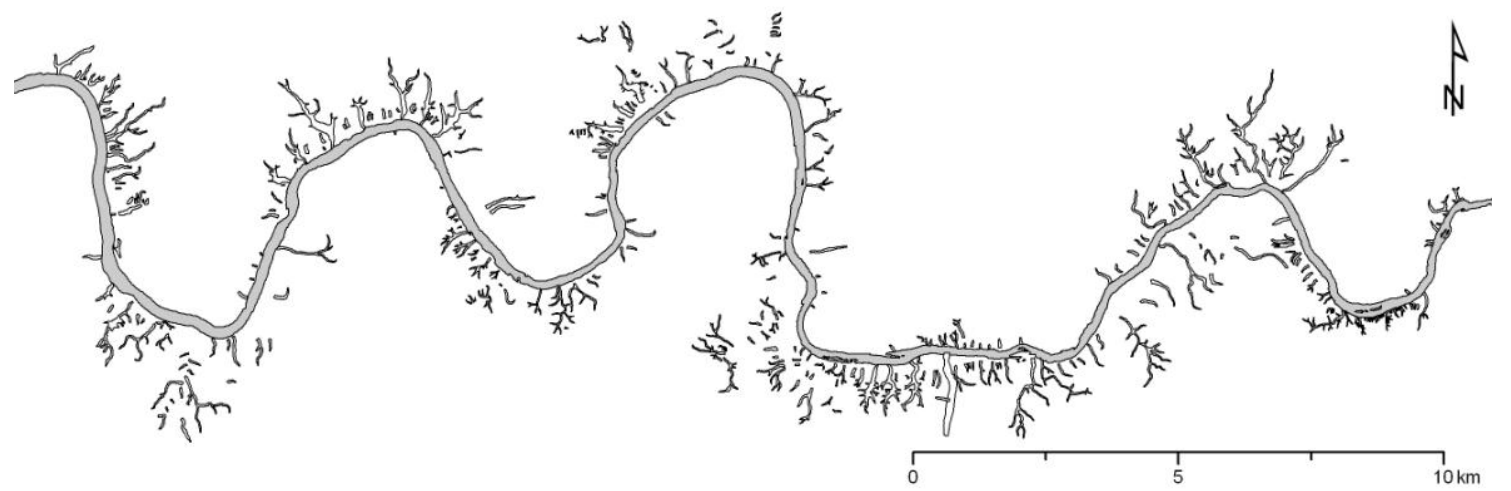

Fig. 9.3. Geographical distribution of gullies within the Upper Daugava spillway valley.

Comparison of the gully network pattern with 'classic' examples reveals its correspondence to the most commonly encountered network type, i.e. a dendritic pattern. The results of geomorphological field studies show that within the spillway valley all morphogenetic types of gullies are represented, i.e. typical gullies, slope gullies, landslide cirque gullies, valley-like gullies and hanging gullies.

The dominant type of landform of linear erosion in the Upper Daugava spillway valley is the typical gully, characterised by considerable dimensions and hydrological connectivity. This type of erosional landform, considering the shape of the gully cross-profile and the stage of development, can be subdivided more specifically into three subtypes: U-shaped or flatbottomed old gullies, $\mathrm{U}+\mathrm{V}$-shaped gullies or gullies of complex origin, and $\mathrm{V}$-shaped gullies. The first, U-shaped or flat-bottomed subtype of the typical gullies, is represented by the largest fluvial erosion landforms among those draining headwater catchments. These geomorphological features, known by the local name sengravas, look similar to small dry grassed valleys and are equivalent to the East European balkas. These flat-bottomed old lateglacial gullies are characterised by impressive morphology, i.e. they are up to $15 \mathrm{~m}$ deep, up to $80 \mathrm{~m}$ wide and up to $2.0 \mathrm{~km}$ long or sometimes even longer, with a typical U-shaped or trapezoidal cross-sectional profile.

The ${ }^{14} \mathrm{C}$ dates and pollen analysis (Soms and Kalnina 2011) reveal that the development of old gullies in the Upper Daugava spillway valley took place before the beginning of intensive agricultural activities and their infilling dates to the Subatlantic ca. 2000 years ago. This also corresponds to the empirically estimated mean annual rates of colluvium deposition, i.e. $0.0011 \mathrm{~m} \mathrm{y}^{-1}$ (Soms and Kalnina 2011). Modelling of paleohydrological conditions by 
approximation of the peak flow discharges $(Q)$ causing gully incision of a given width $(W)$, in its turn, indicates that discharge with values exceeding $48 \mathrm{~m} \mathrm{~s}^{-3}$, which is sufficient for eroding gullies more than $10 \mathrm{~m}$ wide, is virtually impossible under persistent vegetation cover and Holocene climatic conditions in the south-eastern part of Latvia. In this case, development of the largest gullies could be associated with the phase of intensive erosion caused by ice meltwater streams in the Late Pleistocene, at the end of the Late Weischelian glaciation.

The assumption that the old gullies characterised by large dimensions could be periglacial features is consistent with the opinion reported by other researchers who have documented morphologically similar landforms in Western Europe (Langohr and Sanders 1985), in the northeastern part of Poland (Smolska 2007) and the central part of Russia (Panin et al. 2009).

The complex vertical geological structure of this territory and its hydrogeological peculiarities, as well as the fact that the valley acts as the main local zone of groundwater outflow from both confined and unconfined aquifers due to its considerable depth, is behind the formation of a large number of springs here and, as a result, the development of landslide cirque gullies and valley-like gullies. In addition, hanging gullies were formed in the course of the paleogeographic development of the Daugava valley.

\section{References}

Āboltiņš, O. 1994. Augšdaugavas pazeminājums. In: Kavacs, G. (ed-in-chief.), Latvijas daba, 1. Latvijas Enciklopēdija, Rīga, pp. 86-87.

Bronk Ramsey, C., Lee, S. 2013. Recent and planned developments of the program OxCal. Radiocarbon, 55(2-3), 720-730.

Eberhards, G. 1972. Stroyeniye i razvitiye dolin basseyna peki Daugava [Structure and development of valleys of the Daugava river basin]. Zinātne, Rīga, 131 pp. (In Russian).

Juškevičs, V., Skrebels, J. 2003. Quaternary deposits. In: Āboltinš̌, O., Brangulis, A.J. (eds.), Geological Map of Latvia. Scale 1:200,000. Sheet 34-Jēkabpils. Sheet 24-Daugavpils. Explanatory Text and Maps. State Geological Survey, Rīga, pp. 10-29.

Langohr, R., Sanders, J. 1985. The Belgium Loess belt in the last 20,000 years: evolution of soils and relief in the Zonien Forest. In: Boardman, J. (ed.), Soils and Quaternary Landscape Evolution. John Wiley \& Sons, Chichester, pp. 359-371.

Majore, M. 1962. Daugavas ielejas attīstība. Latvijas valsts izdevniecība, Rīga, 77 pp.

Panin, A.V., Fuzeina, J.N., Belyaev, V.R. 2009. Long-term development of Holocene and Pleistocene gullies in the Protva River basin, Central Russia. Geomorphology, 108(1-2), 71-91.

Reimer, P.J., Bard, E., Bayliss, A., Warren Beck, J., Blackwell, P.G., Bronk Ramsey, C., Buck, C.E., Cheng, H., Edwards, R.L., Friedrich, M., Grootes, P.M., Guilderson, T.P., Haflidason, H., Hajdas, I., Hatte, C., Heaton, T.J., Hoffmann, D.L., Hogg, A.G., Hughen, K.A., Kaiser, K.F., Kromer, B., Manning, S.W., Niu, M., Reimer, R.W., Richards, D.A., Scott, E.M., Southon, J.R., Staff, R.A., Turney, C.S.M., van der Plicht, J. 2013. Intcal13 and Marine13 radiocarbon age calibration curves 0-50,000 years cal BP. Radiocarbon, 55, 1869-1887.

Sleinis, I. 1936. Latvijas upes. In: Malta, N., Galenieks, P. (eds.), Latvijas zeme, daba un tauta, 1. Valters un Rapa, Rīga, pp. 192-296.

Smolska, E. 2007. Development of gullies and sediment fans in last-glacial areas on the example of the Suwałki Lakeland (NE Poland). Catena, 71(1), 122-131.

Soms, J. 2006. Regularities of gully erosion network development and spatial distribution in south-eastern Latvia. Baltica, 19(2), 72-79.

Soms, J., Kalnina, L. 2011. Studies of morphology and colluvium of old gullies in the Daugava River ancient valley with respect to the determination of erosion landforms age. Acta Universitatis Latviensis Earth and Environmental Sciences, 767, 75-92 (in Latvian, with English summary).

Zelčs, V., Markots, A. 2004. Deglaciation history of Latvia. In: Ehlers, J., Gibbard, P. L. (eds.), Quaternary Glaciations - Extent and Chronology. Part I: Europe. Developments in Quaternary Sciences, 2. Elsevier, Amsterdam, pp. 225-243.

Zelčs, V., Markots, A., Nartišs, M., Saks, T. 2011. Chapter 18: Pleistocene Glaciations in Latvia. In: Ehlers, J., Gibbard, P.L., Hughes, P.D. (eds.), Quaternary glaciations - extent and chronology. A closer look. Developments in Quaternary Sciences, 15. Elsevier, pp. 221-229. 

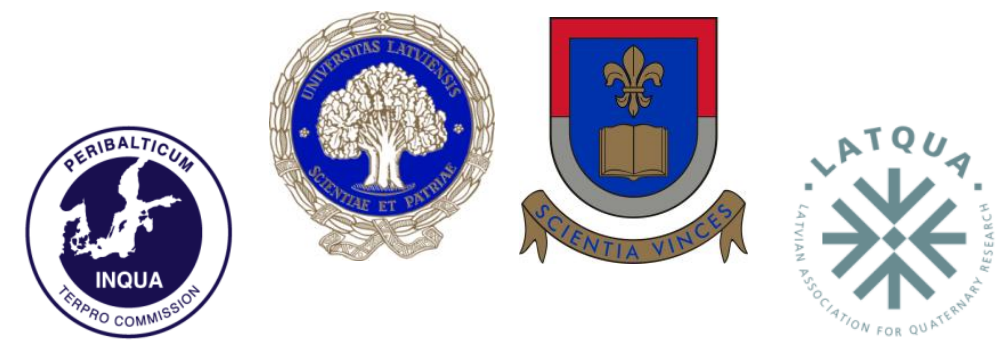

INQUA TERPRO COMMISSION PERIBALTIC WORKING GROUP

UNIVERSITY OF LATVIA

UNIVERSITY OF DAUGAVPILS

LATVIAN ASSOCIATION FOR QUATERNARY RESEARCH

\section{LATE QUATERNARY \\ TERRESTRIAL PROCESSES, SEDIMENTS AND HISTORY: FROM GLACIAL TO POSTGLACIAL ENVIRONMENTS}

EASTERN AND CENTRAL LATVIA

AUGUST 17-22, 2014 


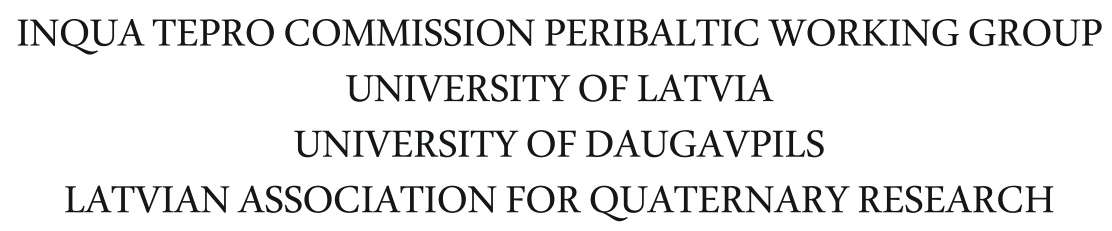

\title{
LATE QUATERNARY \\ TERRESTRIAL PROCESSES, SEDIMENTS AND HISTORY: FROM GLACIAL TO POSTGLACIAL ENVIRONMENTS
}

\author{
EASTERN AND CENTRAL LATVIA
}

AUGUST 16-22, 2014 
Organized by:

University of Latvia

Daugavpils University

Latvian Association for Quaternary Research

INQUA Peribaltic Working Group (INQUA TERPRO Commission)

Organizing committee:

Māris Nartišs (Chair, University of Latvia)

Māris Krievāns (Secretary, University of Latvia)

Aivars Markots (University of Latvia)

Juris Soms (Daugavpils University)

Evija Tērauda (University of Latvia)

Vitālijs Zelčs (University of Latvia)

Contributors:

Ivars Celiņš, Edgars Greiškalns, Ieva Grudzinska, Edyta Kalińska-Nartiša, Laimdota Kalniņa, Jānis Karušs, Māris Krievāns, Kristaps Lamsters, Aivars Markots, Māris Nartišs, Agnis Rečs, Normunds Stivriņš, Juris Soms, Ivars Strautnieks, Santa Strode, Sandra Zeimule, Vitālijs Zelčs

Editors: Vitālijs Zelčs and Māris Nartišs

The English texts of the field guide were revised by Valdis Bērziņš

Recommended reference for this publication:

Zelčs, V. and Nartišs, M. (eds.) 2014. Late Quaternary terrestrial processes, sediments and history: from glacial to postglacial environments. Excursion guide and abstracts of the INQUA Peribaltic Working Group Meeting and field excursion in Eastern and Central Latvia, August 17-22, 2014. University of Latvia, Rīga, 2014, 150 pages.

Sponsored by:

University of Latvia

Layout: Vitālijs Zelčs, Māris Nartišs and Māris Krievāns

ISBN 078-9934-517-60-0

(C) University of Latvia, 2014

This volume is available from:

Faculty of Geography and Earth Sciences

University of Latvia

Rainis Blvd. 19

Rìga, LV1586

Latvia 